\title{
Review of Virginia Woolf's Night and Day
}

\author{
Baker M Bani-Khair (Corresponding author) \\ English Department, Hashemite University, Jordan \\ E-mail: bakribakr@yahoo.com \\ Imad M Khawaldeh \\ English Department, Hashemite University, Jordan \\ Nisreen Al-Khawaldeh \\ Department of English Language and Literature- The Hashemite University, Jordan \\ E-mail: nal-khawaldeh@hu.edu.jo
}

Received: 19-10-2016

Published: 01-03-2017
Accepted: 15-12-2016

doi:10.7575/aiac.ijalel.v.6n.2p.258
Advance Access Published: January 2017

URL: http://dx.doi.org/10.7575/aiac.ijalel.v.6n.2p.258

\begin{abstract}
In this Review article, we have looked at different aspects that make Virginia Woolf's Night and Day one of the most interesting to read and analyze. We particularly focus on the familial and social patterns that distinguish this novel from other ones written by the same author. We also placed a good emphasis on the strength points the novel shows by looking at various elements such as themes of love relationships, modern treatment of plot and content, and more importantly on characterizations. The article revealed that Woolf's Night and Day is rich in terms of its modern and unconventional approach towards characters, plot, style, and thematic content which all make it a successful novel.
\end{abstract}

Keywords: social stability, Virginia Woolf, Night and Day, techniques, styles, modernism, relationships, success, Marriage

\section{Introduction}

Night and Day is a novel by Virginia Woolf published in 1950 by the Hogarth Press, London. The novel actually tackles the issues of love relationships, marriage, and happiness through shedding light on some characters' personal relationships in the novel. The richness of the patterns of love relations makes it appear as a pure social and familial novel. Throughout the whole novel we actually see many characters, especially those who engage in love relationships that either led to marriage, or failure or broken engagement. The novel focuses on Katherine's relationship with Rodney, which finally ends up in a broken engagement. It also tackles the same issue through Katherine's relationship with Ralph, which also ends up in a proposal refusal. Throughout the whole novel, Rodney, Ralph, Mary, Cassandra, and Katherine are all involved in love relationships. What is interesting in this novel, from my point of view, is that the novel begins with the evening time, and also ends with evening time, which is important as to signify and suggest the familial part of marriage, which in reality, Katherine fails to get to throughout her love attempts making the theme of the familial and social stability a central issue here.

Katherine Hilbery is one of the main female characters in the novel who experienced a love relationship with William Rodney which finally broke up soon after engagement. However, what is noticeable here in their relationship that their love lacks congruence and maturity. Katherine's philosophical view about love was totally different from that Rodney has. In fact, both of them have their own views about life and love in different ways. Probably, Rodney's view of marriage and love seems to be realistic and genuine. Katherine's view of marriage and love seems to take the idealistic or the imaginative stream of thought. The novel also highlights the point that love could be more like a shadow, a fantasy, and a farfetched wish that is seen from different perspectives. For example, the love we see between Katherine and Rodney was almost associated with despair and frustration because it lacks the real affection and the real sense of love due to different personal, psychological, and philosophical views of life which results in a broken engagement. Rodney's love dream was associated with failure, despair and sorrow despite his deep love feelings towards her.

\section{Themes and Approaches}

Night and Day is a sentimental novel that suggests how love relationships can affect one's personal life and success. The novel explains how love can associate one's personal dreams of success and self esteem, but it also shows us the totally opposite idea, which is how love can also be synchronized with less confidence, the loss of motivation, and also the absence of trust, faith, and satisfaction, like what we see with Rodney when he realized how his unsuccessful relationship with Katherine was a shocking and disgusting experience that left him so disappointed and frustrated, but 
also changed the way he thinks, and the way he looks at his own life. He realized that one's dignity could be much stronger than love can be. He realized for the first time that there are always possibilities to restore hope again within. As we see in this passage from the novel:

When she reached this point, Rodney pocketed the letter and elaborately looked at his watch. Although the action meant that he resigned Cassandra, for he knew his lost Katharine, for whom his feelings was profound though unsatisfactory, still it appeared to him that there was nothing else left for him to do. He was forced to go, leaving Katherine free, as he had said, to tell her mother that the engagement was at the end. But to do what plain duty required of an honorable man, cost an effort which only a day or two ago would have been inconceivable to him. That a relationship such as he had glanced at with desire could be possible between him and Katherine, he would have been the first, two days ago, to deny with indignation. But now his life had changed; his attitude had changed; his feelings were different; new aims and possibilities had been shown him, and they had an almost irresistible fascination and force. The training of a life of thirty -five years had not left him defenseless; he was still master of his dignity; he rose, with a mind made up to an irrevocable farewell. (343)

\section{Styles and Techniques}

The Novel seems to cover a wide variety of themes. Probably, ideas such as idealism vs. realism is one of the important issues the novel which appear here through showing us how love can be too much idealized or imaginative for some people as we see with Rodney, while it is too much superficial and shallow in others like what we see with Katherine's love towards him. Also, the theme of love and family structure seems to overlap with a multitude of contradictions representing the conflict of human nature, such as the self vs. the other, the conscious vs. the unconscious, happiness vs. sorrow, satisfaction vs. dissatisfaction, and modernity vs. conventionality. For example, happiness through love in this novel is a recurrent theme that the whole novel talks about. As we notice in this quotation that shows us how Rodney looks at happiness through his own relationship with Katherine, saying, "I don't know what one means by happiness," he said briefly, having to step aside in order to avoid a groom with a bucket. "Why do you think I shall be happy? I don't expect to be anything of the kind. I expect to be rather less unhappy. I shall write a book and curse my charwoman-if happiness consists in that. What do you think?"(248)

Each one of the characters symbolizes love in different ways especially in terms of modernity and traditionalism which are represented through the two characters: Katherine and Cassandra. While Katherine tends to philosophize and doubt everything around her through her own critical and complex views of life and concepts, we see Cassandra maintains the conventional and traditional role a woman had in the Victorian age. Rodney himself finds Katherine's patterns of thinking and living difficult to understand. As we see in this passage when Rodney was talking to Miss Datchet, about Katherine, saying, "Would you believe it, Miss Datchet," William continued, "Katherine doesn't like Titian. She doesn't like apricots, she doesn't like peaches, and she doesn't like green peas. She likes the Elgin marbles, and grey days without any sun. She is a typical example of the cold northern nature. I come from Devonshire."(179) Katherine modernist and idealistic views of love and marriage tend to cause her more dissatisfaction, suffering, loneliness and gloominess as we see by the end of the novel.

\section{Modernism}

The techniques and the styles that Woolf uses in this novel are highly modern, which in fact meet the concept of modern standards regarding literary movement, especially her essential focus on feminism. For example, one of the most prominent techniques that the writer uses in this novel is the stream of consciousness that primarily reflects the inner turmoil and dreams of the female characters. Also, the dialogue is widely used in this novel which actually fits the whole thematic issue of the human relations, especially within men-women relationships framework that depend on dialogue rather than narration. What is also modern about this novel is its feminine centrality, and the attempt to make the women's voice louder, which from my point of view, is different from the other novels we have read by Virginia Woolf, such as To The Light House. Despite the fact that to The light house shows us how feminine creativity is the central issue, but that creativity represented by Lily's character was influenced or curbed somehow by male figures. Cassandra, however, in Night and Day represents the opposite stream of thought, the totally opposite personality to Katherine in the sense that she seems to be much more realistic in her love towards Rodney, which probably leads to a successful marriage at the end. The use of different styles and the mixture of the new and the old ones makes the novel highly interesting to read. Using the new mould of modern writing and referring to the classics at the same time makes the novel a brilliant mixture of modernist stylistic writing.

We see that the writer's style has successfully matched the modernist perspectives of the modernism movement in terms of the abundance of expressive images, descriptive language, and by also using different stylistic techniques, like the use of soliloquy, internal monologues, and the apparent use of the modern dialogue. We guess the names of the characters that Woolf uses are classic and Shakespearean. Names like Henry, William, Katherine, Charlotte, Edward, are always seen in Shakespeare's plays. Woolf has referred to Shakespeare many times in this novel, as we when Rodney was talking to Miss. Datchet about Katherine saying, "She pretends that she has never read Shakespeare. And why should she read Shakespeare, since she is Shakespeare." (182)

\section{Conclusion}

From our point of views, Night and Day is one of the best novels we have read. Having read it again through the lens of a critical psychoanalytic approach makes the novel appear to me as one of the best masterpieces. The novel is full of 
aspirations, family dreams, and variant philosophical attitudes towards marriage, love, and happiness. Throughout the whole novel, we find many intense psychological moments which make us think of our own being and existence, and our relationships with the self and the others. We think that the writer succeeded in explaining how true love can be an influential factor in one's life either positively, or negatively through changing one's views about certain concepts like

love, satisfaction, dignity, and marriage. We really like how the writer could express the failure of love relationship through showing the domination of the feminist dialogue creating a wide gap between males and females, and probably that female-centered dialogue caused further distance and miscommunication between lovers. However, Night and Day remains of the most powerful novels we have ever read about love relationships due to its artistic and realistic treatment of characters and actions.

\section{Reference}

Woolf, V. (1950). Night and Day. London: The Hogarth Press. 